\title{
A divulgação da ciência e o resgate da curiosidade infantil
}

Vania Mintz ${ }^{1}$

MASSARI, Luísa (Org.). O pequeno cientista amador - a divulgação científica e o público infantil. Rio de Janeiro: Vieira \& Lent/UFRJ/FIOCRUZ, 2005. (Série Terra Incógnita).

A divulgação científica vem se consolidando como um campo de estudo no Brasil, seja através do resgate de sua história, seja por sua importância na atualidade. O estudo da divulgação da ciência voltada para o público infantil vem auxiliar na seleção e análise das informações dirigidas às crianças, assim como colaborar na construção de um conhecimento comprometido com valores educativos.

O pequeno cientista amador é uma coletânea de estudos sobre diversos contextos de divulgação da ciência, tais como: materiais direcionados para atividades escolares (jogos e livros), veículos de comunicação (televisão e revistas), bem como museus e acampamentos. A obra foi organizada por Luísa Massari, jornalista especializada em ciência e atual coordenadora do Centro de Estudos do Museu da Vida e da Casa de Oswaldo Cruz/ Fiocruz.

O livro reúne artigos que buscam diferentes formas para responder à questão levantada pela autora na sua apresentação: temos explorado adequadamente a curiosidade infantil?

A prática de leitura da revista científica brasileira Ciência Hoje das Crianças pelo público infantil é o tema do artigo de Guaraciara Gouvêa, professora do Programa de Pós-graduação em Educação da UFRJ. Sua análise considera desde o contato afetivo com a revista como objeto, até a relação que a criança estabelece com as informações veiculadas. Outra revista de divulgação de ciência para crianças e jovens, a mexicana Chispa, é apresentada por Guadalupe Garza. A opção editorial dessa revista, que existiu de 1980 a 1998, era a de situar o conhecimento científico num

1 Coordenadora do $3^{\circ}$ ciclo da Escola da Serra (Belo Horizonte/Brasil). vaniamintz@gmail.com. 
contexto cultural mais amplo, mostrando como a ciência está associada à vida comum. Garza aponta como se deu o processo de escolha do públicoalvo, assim como os artifícios utilizados para suscitar a curiosidade das crianças.

A divulgação da ciência em programas televisivos para crianças é o tema tratado por Denise Siqueira, professora de comunicação social da Universidade Estadual do Rio de Janeiro. Ela analisa como se dá a construção da imagem do cientista e, ao descrever a forma distorcida como os personagens são apresentados em diversos desenhos de animação bastante veiculados para o público infantil, traz interessantes observações para a discussão do potencial (de)formador da programação televisiva.

Quatro artigos abordam a relação entre o prazer e o processo de aprendizagem: Virgínia Schall diz das vantagens de se trabalhar a divulgação científica através de jogos e livros criados com essa finalidade; Eugenio Díaz descreve a proposta e a estrutura dos acampamentos científicos que ocorrem desde 1999 com crianças do Chile; Denise Studart apresenta um trabalho cujo foco é a interatividade nos museus de ciências, e o artigo de Martha Marandino e Luciana Martins também traz o museu como tema, através de um relato fictício da visita de uma família a um museu.

Destaque para o artigo "A história natural dos pequeninos", de Roquete-Pinto, originalmente publicado em 1927. Edgard Roquete-Pinto (1884-1954) foi antropólogo, professor de história natural e participou ativamente da radiodifusão educativa no Brasil, fazendo uso também do cinema como mais um meio de divulgação da ciência. Partindo de uma citação de Thomas Huxley, que foi um dos principais proponentes da educação científica na Inglaterra do final do século XIX, Roquete-Pinto inicia seu artigo fazendo uma crítica à metodologia de ensino de ciências naturais:

Os métodos de ensino são anacrônicos, atrasados, rudimentares e incompletos, incapazes de formar cidadãos dignos da época, eficientes e fortes, em condições de lutar vantajosamente com as dificuldades da vida moderna, em que, pelo formidável impulso do progresso, o conhecimento da natureza é questão fundamental.

A não ser pelas diferenças de linguagem, o leitor desprevenido pode pensar que tal artigo seja recente, devido à atualidade de suas críticas. $O$ que pode causar certo estranhamento é uma exacerbada valorização do 
"progresso" e da necessidade de o homem "poder explorar melhor a natureza, dominando-a ou dirigindo-a", algo tido como problemático dentro da perspectiva que hoje se apresenta como ecologicamente correta.

Assim como Huxley, Roquete-Pinto sai em defesa de um ensino de ciências que não seja dogmático, mas que parta do princípio de que se faz necessário o desenvolvimento de habilidades científicas. Sua crítica recai sobre os "Lição de Coisas" - manuais didáticos difundidos no Brasil, e em diversos países, no final do século XIX. Esses manuais foram criados como contraponto à metodologia tradicional de ensino da época, centrada na memorização, e utilizavam como princípio o Método de Ensino Intuitivo, que considera que as atividades escolares devem se apoiar no exercício dos sentidos. Na opinião de Roquete-Pinto, essa proposta "não serve", pois "a noção elementar de lei natural deve e pode ser logo apresentada". Portanto, o autor diz da necessidade da incorporação da noção de processo, necessária ao entendimento dos fenômenos da natureza.

No campo da divulgação da ciência, Roquete-Pinto aponta outras formas de promoção da "familiarização da criança com o meio" - como, por exemplo, a colocação de placas nas árvores das cidades, indicando seus nomes, desconhecidos pela população - e não deixa de fazer uma crítica à forma superficial de aproveitamento dos espaços de divulgação da ciência pelos professores.

O artigo deixa claro que o discurso atual - da necessidade do ensino da ciência para a formação da cidadania - era corrente no início do século $\mathrm{XX}$, e nos faz pensar na importância desse debate iniciado em épocas passadas.

A crítica ao ensino da ciência pela escola é unânime entre os autores, pois praticamente todos os artigos colocam a divulgação científica como sendo um importante recurso para suprir a lacuna deixada por um ensino enfadonho ou pela utilização de materiais didáticos inadequados. Portanto, fica a pergunta: como a divulgação científica, com todas as suas possibilidades, poderia ser incorporada pela escola?

Recebido em: 05/10/2006

Aprovado em: 21/11/2006 